\title{
Modern dance commodification strategy in tourism promotion (Study on the modern dance community in Kupang city)
}

Victor C. B. Raya ${ }^{1}$, Rolland E. Fanggidae ${ }^{2}$, Apriana J. Fanggidae ${ }^{3}$

Nusa Cendana University ${ }^{1,2,3}$

vicky.raya345@gmail.com ${ }^{1}$,rolland_fanggidae@staf.undana.ac.id ${ }^{2}$, aprianafanggidae@yahoo.co.id ${ }^{3}$

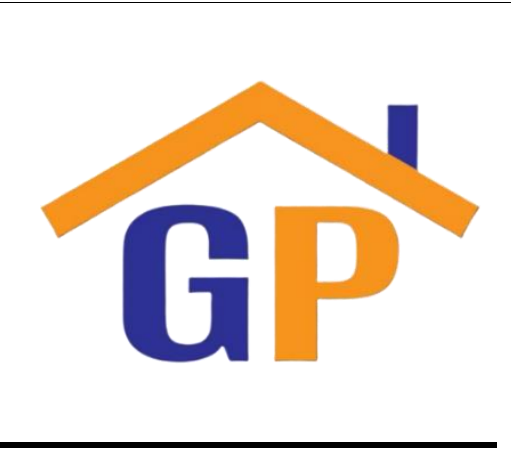

Article History

Received on 19 February 2021

Revised on 19 March 2021

Accepted on 22 March 2021

\begin{abstract}
Purpose: This study aimed to describe the modern dance commodification strategy in promoting cultural tourism in East Nusa Tenggara Province.

Research methodology: The research method used in this research is a qualitative method. Respondents used in this study were 15 people. Data processing was performed using a SWOT analysis.
\end{abstract}

Results: According to the analysis results, the most appropriate strategy for the modern dance community in developing cultural tourism in East Nusa Tenggara is to work together with various parties, create online competitions, innovate with culture, and organize independent events by the dancer community.

Limitations: This study only discusses the strategy of the commodification of modern dance in tourism promotion in East Nusa Tenggara.

Contribution: This research can become scientific information for students specifically studying tourism.

Keywords: Modern dance commodification, Tourism promotion

How to cite: Raya, V. C. B., Fanggidae, R. E., \& Fanggidae, A. J. (2020). Modern dance commodification strategy in tourism promotion (Study on the modern dance community in Kupang city). Journal of Sustainable Tourism and Entrepreneurship, 1(4), 333-347.

\section{Introduction}

Indonesia is a nation with much diversity, both in terms of customs, culture, religion, ethnicity and language, and natural beauty. These existing resources, if managed properly, can serve as potentials for the prosperity of the people and advancing the Indonesian nation. One thing that can be developed is in the tourism sector. Over time, tourism in Indonesia has grown and developed, so that tourism has become an alternative source of income for regional income and for foreign exchange (Widyasti, 2013), so the tourism industry needs to be further developed so that it can be better known by tourists throughout world. Mbuik (2013) states that the Province of East Nusa Tenggara (NTT) is one of the provinces in Indonesia that has a lot of potential in the tourism sector, especially its natural beauty and culture such as various regional dances that have almost disappeared, traditions and customs, ways of dressing, and art forms, screams or in the NTT area are called koak and there are many other types of culture, so they need to be maximized while having the potential as a new tourism object destination. One type of tourism that is developing in NTT is cultural tourism, where culture is the main attraction. According to Nurdiansyah (2014), culture as a form of human reason or mind is formed from many elements, ranging from belief systems, religion, language, livelihoods to art which later become a developing way of life. Silberberg (in Utomo, 2014) said that cultural tourism which includes cultural heritage as part, of course, relates to visits by people from outside the 
local community, whether it is motivated entirely or partly from the interests of art, science or lifestyle/heritage of an offering community, region, group or institution.

In the context of cultural tourism, art has become a very important or interesting tourist attraction. The arts in it include music, dance and other performing arts, both traditional and modern. From an artistic point of view, the tourism industry's development has actually encouraged the growth of creativity of art actors in developing their creations, especially in the cultural tourism industry (Muhamad, 2013). One form of art is dance, where dance is the movement of all members of the human body arranged in harmony with the rhythm of music and has a specific purpose. With art development, various kinds of dance can be recognized, namely traditional spiritual dance performed at traditional ceremonies, ballet and modern dance (Mulyani, 2016). The art of dance has developed from time to time along with the passage of foreign cultures that have entered the culture until the emergence of modern dance.

Modern dance or usually called modern dance has great potential to help develop cultural tourism. In general, modern dance was created by teenagers and is only looking for popularity (Horosko, 2002). Modern dance is in great demand by adolescents because modern dance is a dance art from America that has entered it so that it affects teenagers who are very fast following the times (Dewi, 2013). The role of modern dance is very important in human life. Various events that exist in human life take advantage of this modern dance to support the procession of events according to their interests. The community needs it not only for aesthetic satisfaction, but also for other events (Laili, 2016).

Many people in Kupang City are fond of modern dance, even from an early age they have been taught how to modern dance. There have been many course places that have opened dance courses with a modern genre for children. Not only children who dance with modern dances, teenagers to adults also dance modern dances. In fact, many events are held to compete and participate in these dance events. Children can take part in these competitions and events; it is not uncommon in dance competitions to produce professional dancers. This makes researchers interested in conducting research using modern dance communities in the city of Kupang as objects in the development of cultural tourism in East Nusa Tenggara, starting to fade from society due to the incoming external which affects lifestyle, or culture. Irianto (2016) argues that this is a problem for art actors to work harder to develop the art produced so that this regional art does not disappear and can compete with arts from other regions that can expose the regional arts. Therefore, one of the issues that stand out in today's development is the emergence of the term commodification.

Commodification is the process of changing goods or services that previously followed nonmarket social rules into a subject that follows market rules (Irianto, 2016). In evolutionary terms, Greenwood (in Pitana, 2005) states that the relationship between tourists and local communities causes a process of commoditization and commercialization of cultural elements such as art and belief systems, giving rise to the term cultural commodification. Thus, the commodification of culture is associated with the commercial process (capitalization) of culture into objects, quality and cultural symbols used as products (commodities) to be sold in the market (Sendra, 2013). For this reason, unconsciously, this cultural commodification has become a challenge for the development of cultural tourism, where this development triggers every cultural product, especially regional arts, which have been the hallmark or identity of an area, must be required to compete with other cultural products.

The most important thing in advancing cultural tourism in NTT is introducing various kinds of cultures in NTT. This is one of the tourism problems in NTT because in fact there are still many tourism potentials that are not yet known by the wider community (Mbuik, 2013). For this reason, one way to overcome this is by increasing tourism promotion in NTT. It is hoped that it will impact the outside community so that they can reach tourism in NTT with the availability of easily available information. According to Tjiptono (in Mayasari, 2014), promotion is defined as promotional 
activities that are useful for spreading information, influencing/persuading and increasing loyalty to the products offered. Yonathan (2012) states that promotion is carried out as an effort to increase the attractiveness of tourist objects and inform or notify existing tourist objects and attractions. With the concept of promotion, modern dance can introduce a region's cultural tourism to the outside world.

Based on the background of the problems and examples of achievements from the modern dance community above and to get to know the potential of modern dance in Kupang City as a way of promoting cultural tourism in the development of cultural tourism in East Nusa Tenggara in the cultural commodification that is happening in the development of cultural tourism Currently, in order to compete with cultural tourism products in other areas, the authors are interested in conducting research with the title "Modern Dance Commodification Strategies in Tourism Promotion".

\section{Literature review}

\subsection{Cultural tourism}

According to Nafila (2013), cultural tourism is one type of tourism, which is one type of tourism that makes culture the main attraction. In this cultural tourism, tourists will be guided in addition to recognizing and understanding the local community's culture and wisdom. In addition, visitors will be spoiled with sights, historical places, museums, representations of the values and life systems of the local community, art (both performing arts and other arts), and typical culinary delights from the indigenous people or local communities concerned.

Meanwhile, Golder (Nafila, 2013) argues that cultural tourism includes all aspects of the journey to learn from each other's lifestyles and thoughts. This definition is more directed at the purpose of visitors or tourists visiting cultural tourism, more on understanding the essence and comparing it with the cultural conditions it has as a new understanding, of course, in addition to the aesthetic value contained therein.

Timothy and Nyaupane (2009) state that cultural tourism, referred to as heritage tourism, usually depends on living or built elements of culture and leads to the use of the tangible and intangible past as tourism research. This includes existing culture, which is handed down from the past, non-material heirlooms such as music, dance, language, religion, culinary traditions, artistic traditions and festivals and material heritage such as built-in cultural environments including monuments, cathedrals, museums, historical buildings, castles, archaeological ruins and relics.

Ahimsa-Putra (2004) defines sustainable cultural tourism as cultural tourism that can be maintained. The growth of a sustainable cultural tourism model appears to be a reaction to tourism's negative impact, which emphasizes too many economic goals (Suranti, 2005), which aims to strive for existing cultures to remain sustainable. Culture must also be the main attraction of this tour in order to maintain the existence of cultural tourism. In other words, there must be good management of cultural heritage.

According to McKercher \& Du Cros (2002), cultural tourism's growth coincides with the emergence of mass appreciation in need to maintain and conserve critical cultural assets and cultural heritages. Furthermore, they stated that tourism could be seen as a double-edged knife for the cultural heritage management community. On the one hand, the need for tourism provides a strong political and economic justification for expanding conservation activities. However, on the other hand, increased visits, excessive use, inappropriate use and commodification of the same assets without appreciating cultural values pose a threat to the integrity of the assets. Commodification is often contrary to the principles of cultural heritage management.

MacCannel and Greenwood (in Soeriaatmaja, 2005) questioned the commodification of culture in which culture becomes the servant of consumerism so that deep values, social functions and authenticity are lost to something superficial. Soeriaatmaja explained that the term authenticity could actually reflect an object, culture or environment. 
From some of the expert opinions above, it can be concluded that what is meant by cultural tourism is a tour made by tourists to feel and see the attractiveness of the arts and culture and lifestyle of an area that has been passed down from the past.

McKercher (2002) explains that cultural tourism consists of 4 elements: tourism, cultural heritage assets, consumption of products and experiences, and tourists. These elements will be described as follows:

1. Tourism

Cultural tourism is a form of tourism itself, not a way of managing cultural heritage. As a form of tourism, cultural tourism activities will attract visitors from outside the local area who travel for pleasure in a limited time and know little about the assets visited.

2. Use of Cultural Heritage Assets

The International Council on Monuments and Sites or ICOMOS (1999) defines heritage as a broad concept that encompasses tangible assets, such as the natural environment and the cultural environment including landscapes, historical places, built sites and environments and intagible assets, such as cultural practices, knowledge and life experiences. These assets are identified and conserved in view of their intrinsic value and significance for the community rather than extrinsic values such as tourist attractions.

3. Consumption of Products

Cultural tourists want to consume a variety of cultural experiences. To facilitate this consumption, cultural heritage must be converted into cultural tourism products. The conversion process is not good in some parties' eyes, but it is one way of good development and sustainable management of cultural tourism products.

4. Tourist

Cultural tourism takes into account the tourists. Many definitions say that all cultural tourists are motivated or decide to travel for deep learning, full of experience or reasons for selfexploration. But it is not uncommon for tourists who only visit a cultural heritage to know it or even just part of a trip.

Meanwhile, according to Cooper in Sunaryo (2013) explains that tourism consists of four main components, namely:

1. Attraction which includes the uniqueness and attractiveness based on nature, culture and artificial/artificial.

2. Accessibility, which includes the ease of means and transportation systems.

3. Amenities that support tourism support and support facilities.

4. Public facilities that support tourism activities.

\subsection{Commodification}

According to Piliang (2004), commodification is making something that was not a commodity before, so it is now a commodity. At the same time, a commodity is produced and exchanged for something else, usually money to obtain more value or profit. According to Shepherd (2002), commodification is the conversion of an object to become a commodity. As tourism demand increases, cultural commodification is inevitable because tourists want to experience a different culture from their place of origin.

Barker (2005) states that commodification is a process associated with capitalism. Objects, qualities and signs are transformed into commodities, that is, something whose main purpose is to sell in the market. Commodification can be said to be a symptom of capitalism to expand the market, increasing profits as much as possible by making products or services that consumers like. Goods are packaged and shaped in such a way as to be preferred by consumers. Meanwhile, the characteristic of the commodification itself is that there is a change in format that adapts to consumer desires. 
Consumers or audiences are the main goal, reaching the audience is expected to bring benefits. Nurdiyansah in Thei et al (2019) said commodification includes a commercial relationship where there are buying, selling activities, and exchanges that occur in cultural products that were previously only used for their own circles with special meanings and functions.

Mosco also writes a different concept regarding commodification in his book entitled "The Political Economy of Communication" (in Paok, 2012); commodification is the use of media content seen from its use as a marketable commodity. Commodification can be assumed as a process of transforming goods and services from their use-values into commodities that are oriented towards their market exchange rates, because exchange rates are related to markets and consumers, the commodification process is basically changing goods/services to suit the wants and needs of consumers. In transforming from use value to exchange value, the mass media always involves the media crew, the audience, the market, and the state if each of them has an interest.

Lukmantoro (2004) argues that in the cultural industry, in addition to commodification, which treats products as commodities to be traded, there also tends to be standardization and masification. Standardization means establishing certain criteria that make it easier for the products of the cultural industry to be easily digested by the public. Masification means producing various cultural products in mass quantities in order to gain the widest market share. In the development of this industry, it has resulted in what is known as popular culture.

Based on the explanation of the experts above, it can be concluded that commodification is something that previously only had use value to become an object that had economic value so that it could be traded.

As for the forms of commodification according to Vincent Mosco (in Paok, 2012), include:

1. The commodification of content

The commodification of content is the process of changing messages from a collection of information into a meaning system in the form of marketable products. In another explanation, it is referred to as the process of changing messages in a set of data into a meaning system in such a way as to become a marketable product.

2. The commodification of audience

The commodification of Audience is the process of modifying the role of readers / audiences by media companies and advertisers, from their initial function as media consumers to audience consumers other than the media. In this process, the media company produces audiences through a program/impression which is then sold to advertisers. There is a process of mutually beneficial cooperation between media companies and advertisers, where the media company is used as a means to attract audiences, which are then sold to advertisers. Audience commodification is divided into two, namely Instrinsic Commodification and Extrinsic Commodification.

3. Commodification of labor

The commodification of Labor or the commodification of workers or labor is a transformation of the work process in capitalism, where the skills and working hours of workers are made into commodities and are rewarded with salaries. Labor is the unitary concept of conception, or invasion force, imagine and the work of design and execution, or the power to carry it out. In the process of commodification, the modal act is to separate the conception from the execution, the skill or skill from the ability to carry it out. In this commodification of labor, there are two processes that can be considered. 


\subsection{Modern dance}

According to dance expert Kenneth Macgowan in his book "The Living Stage: A Story of The World Theater" (in Dewi, 2016), which states that modern dance is a dance that is dominated by emotions or feelings which are the natural characteristics of human emotions that have the urge to want to be free, then this type of dance leads to more freedom from tradition. Free here is free to express motion, which is not required by the existing patterns.

According to Horosko (2002), a modern dance expert said that modern dance is one of the most difficult genres to define by technique and is a form of dance that was formed and developed since the early 20th century. Modern dance is not always fast or slow or performed for specific music or any music. It does not necessarily highlight specific physical skills. This is good and great news from the point of view of choreographers and dancers because, in theory, it gives them endless possibilities to explore motion. From the opinion of the experts above, it can be concluded that modern dance is a type of dance that developed since the early 20th century where this dance is performed with emotion or feeling freely to explore movements and is not bound by tradition so that it is not always tied to patterns.

The history of modern dance began in the 1900s in the United States and began to develop in Indonesia in the 1980s. Modern dance movements, which are the self-expression of each individual, are the main keys of any existing technique. In line with the times in Indonesia, modern dance began to mushroom among teenagers and first developed in Surabaya. Therefore, several individuals began to form groups that exchanged ideas and taught and learned how modern dance is. These groups are then called 'crew' and form a group of crews with a technique with the type of modern dance they are interested in, called the community (Dewi, 2016). This modern dance then spread to the city of Kupang, which has many cultures. For this reason, the potential for modern dance communities and events in the city of Kupang is now enormous and attracts the interest of the community, especially teenagers, so that the number of people interested in modern dance is increasing.

According to Yuniarvi (2017), which are elements of modern dance, namely:

1. Choreography

Choreography comes from the word choreographer, which means an expert at creating and changing motion is called a choreographer. Choreography is the art of creating and changing dance movements.

2. Music

The dance presentation cannot be separated from the accompanying music, because music as a dance accompaniment can help the audience generate imagination in enjoying dance accompaniment. Good and appropriate dance accompaniment also helps the dancer realize the expression of movement and the dancer's characteristics. Dance accompaniment music can be used as the beginning, link, and ending of a section or scene that is ongoing or will take place

3. Makeup and Clothing

Make-up is to change personal character to strengthen expression and increase the attractiveness of a dancer's appearance and clothing in dance is all the views and accessories worn by the dancer on the stage which serves as a support for the content or theme of the dance and to clarify certain roles in presenting a dance.

4. Property

Property is a form of motion support equipment as a form of expression because of its identity as a tool or equipment, so presence is realistic or symbolic.

Horosko (2002) states that there are several types of modern dance, namely:

1. Robot

2. Breakdancing

3. B-boying or what is often referred to as breakdancing 

4. Popping
5. Locking
6. Hip-hop Dance
7. Ballroom Dance
8. Contemporary
9. Shuffle Dance

\subsection{Tourism promotion}

Nurulwasi (2017) said that promotion in the marketing of tourism products plays a role in supporting transactions by informing, persuading, enhancing and differentiating the promoted tourism products from other tourism products. Promotional activities that must be carried out must be diverse, promotional activities must also be carried out by establishing a reliable information system and building good cooperation with other tourism information centers (Soebagyo, 2012).

According to Suryadana and Octavia (2015) promotion in tourism is a one-way flow of information designed to direct potential tourists or tourism business institutions to actions that can create exchanges (buying and selling) in the marketing of tourism products.

According to Gromang (2003), tourism promotion departs from predictions and is related to efforts to trigger the possibility of tourism sales. This tourism promotion includes all planned activities, including disseminating information, advertisements, films, brochures, guidebooks, posters, works of art, and others.

According to Kotler and Keller (2009) Promotion is a means used by companies in an effort to inform, persuade and remind consumers directly or indirectly about the products and brands they sell, while according to Kotler and Armstrong (2010) Promotion is an activity of communicating product excellence and persuading the target consumer to buy it.

According to Tjiptono (2019) Promotion is a form of marketing communication that seeks to spread information, influence, or persuade and remind the target market or company and its products to be willing to accept, buy and be loyal to the products offered by the company concerned.

According to the experts above, it can be concluded that tourism promotion is a form of effort to inform, persuade, and influence tourists about the tourist attractions in an area to increase tourist visits in the tourist area.

According to Kotler and Keller (2009), the promotional marketing communication mix consists of seven main ways of communication, namely:

1. Advertising

2. Sales Promotion

3. Public Relations and Publicity

4. Direct Marketing

5. Personal Selling

6. Word of Mouth Marketing

7. Event Marketing

\section{Research methodology}

This research was conducted in Kupang City, East Nusa Tenggara. In this study, Respondents were 15 modern dance dancers with the criteria of having participated in or participated in modern dance events with cultural elements in Kupang City. Data collection was carried out by means of interviews and observations. The type of data used in this research is qualitative data. The data that researchers have obtained is then processed using a SWOT analysis. Zuhdin, Amelia and Syukur 
(2015) define that the analysis of Strength, Weakness, Opportunities and Threats (SWOT) is a method of developing a company or organizational strategy that is one unit or a single business.

\section{Results and discussions}

\subsection{Results}

Based on interviews conducted with 15 respondents, strengths, weaknesses, opportunities, and threats were found with the following details:

1. Strengths
a. Very good at dancing
b. Grab the audience's attention
c. Creativity owned by the community
d. The number of dancers is quite a lot
e. Interesting and unique dances
f. Connections or acquaintances within or outside the area are quite a lot

2. Weakness
a. Lack of costs to express culture in NTT outside the region or abroad by participating in events or competitions that are there
b. Lack of knowledge and self-awareness of each dancer about the importance of customs and culture in NTT
c. Lack of confidence for a team just starting a career in modern dance

3. Opportunities
a. There are events such as competitions, ethnic and modern dance concerts
b. Make videos and upload them to YouTube or other social media so that the outside community can see them

4. Threats
a. It loses its appeal from the outside because of its different dancing styles from modern dance styles
b. Lack of events with the theme of NTT culture
c. The incessant types of tourism promotion activities outside the NTT region or abroad can be a stumbling block to tourism development in NTT
d. Lack of intervention by the government in helping promote cultural tourism in NTT, thus making modern dance communities in Kupang City always move on the basis of togetherness only
e. A pandemic period like the one currently happening is the Covid-19 outbreak
f. The work of modern dance communities from areas outside NTT that are able to compete with modern dance communities in Kupang City

Based on the above findings, a Grand Matrix Strategy is compiled as follows:

Matrix grand strategy modern dance community

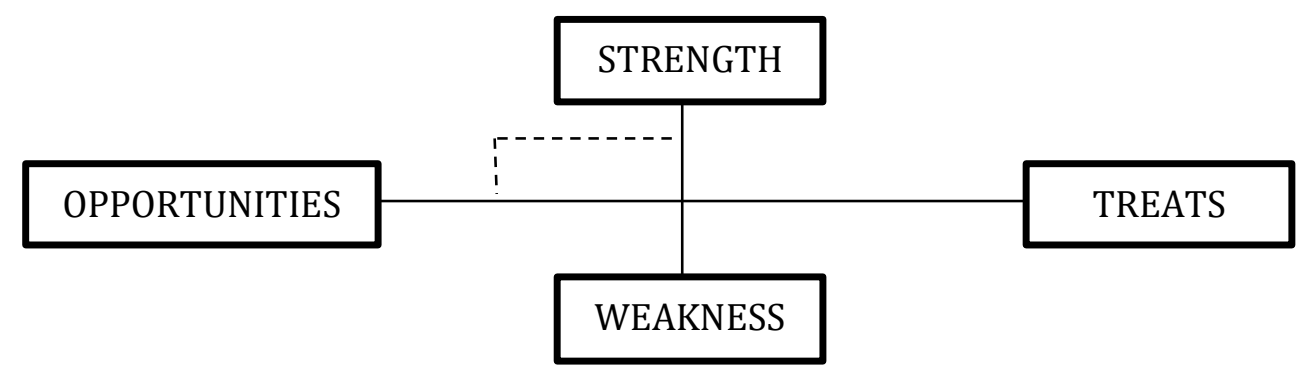

Figure 1. Matrix grand strategy modern dance community 
Based on the image in the diagram above, the modern dance community in Kupang City is in quadrant II, where the community needs to seriously evaluate their approach to the development of their cultural tourism promotion. Even though the community industry is growing, the community will not be able to compete effectively and how the community can change in the best way to improve its competitiveness because the community in quadrant II is in a fast-growing industry. Incentive strategies (rather than integrative or verifiable) are usually the first option thought of. For that, the community must have unique competencies or competitive advantages by utilizing existing strengths.

Furthermore, to be able to determine the right strategy based on the aspects of Strengths, Weaknesses, Opportunities and Threats found by the researcher, a SWOT analysis is carried out by compiling a SWOT matrix as follows:

Table 1. SWOT Matrix

\begin{tabular}{|c|c|c|}
\hline EFAS & $\begin{array}{l}\text { Strengths } \\
\text { a. Very good at dancing } \\
\text { b. Grab the audience's attention } \\
\text { c. Creativity owned by the } \\
\text { community } \\
\text { d. The number of dancers is quite a } \\
\text { e. Interesting and unique dances } \\
\text { f. Connections or acquaintances } \\
\text { within or outside the area are quite } \\
\text { a lot }\end{array}$ & $\begin{array}{l}\text { Weakness } \\
\text { a. Lack of costs to express culture in } \\
\text { NTT outside the region or abroad } \\
\text { by participating in events or } \\
\text { competitions that are there } \\
\text { b. Lack of knowledge and self- } \\
\text { awareness of each dancer about the } \\
\text { importance of customs and culture } \\
\text { in NTT } \\
\text { c. Lack of confidence for a team just } \\
\text { starting a career in modern dance }\end{array}$ \\
\hline $\begin{array}{l}\text { Opportunities } \\
\text { a. } \\
\text { There are events such as } \\
\text { competitions, ethnic and modern } \\
\text { dance concerts } \\
\text { b. } \\
\text { Make videos and upload them to } \\
\text { YouTube or other social media so } \\
\text { that the outside community can see } \\
\text { them }\end{array}$ & $\begin{array}{l}\text { SO strategy } \\
\text { a. Incorporate NTT cultural elements } \\
\text { into concepts, choregraphy, music, } \\
\text { costumes and property when } \\
\text { participating in events, be it } \\
\text { competitions, festivals or other } \\
\text { events } \\
\text { b. Ask for help from acquaintances } \\
\text { outside the region to find } \\
\text { information about events outside } \\
\text { the region so that they can display } \\
\text { elements of NTT culture } \\
\text { combined with modern dance } \\
\text { outside the region } \\
\text { Making videos combining } \\
\text { elements of NTT culture with } \\
\text { modern dance and uploading them } \\
\text { to social media }\end{array}$ & $\begin{array}{l}\text { WO strategy } \\
\text { a. Combining NTT cultural elements } \\
\text { in participating in every } \\
\text { competition or filling in events at } \\
\text { events so that it can increase } \\
\text { community awareness about the } \\
\text { importance of NTT cultural } \\
\text { tourism and earn money when } \\
\text { winning championships or getting } \\
\text { paid for filling events } \\
\text { b. Uploading dance videos blended } \\
\text { with NTT culture on social media } \\
\text { so as to attract people's attention so } \\
\text { that they are interested in } \\
\text { following modern dance so that } \\
\text { they can get new dancers and } \\
\text { increase the confidence of the new } \\
\text { team. } \\
\text { Make your own event using the } \\
\text { concept of NTT culture in it }\end{array}$ \\
\hline \begin{tabular}{ll}
\multicolumn{1}{c}{ Threats } \\
a. & $\begin{array}{l}\text { It loses its appeal from the outside } \\
\text { because of its different dancing }\end{array}$ \\
styles from modern dance styles \\
b. & Lack of events with the theme of \\
NTT culture & \\
c. The incessant types of tourism & promotion activities outside the \\
NTT region or abroad can be a \\
stumbling block to tourism \\
development in NTT
\end{tabular} & \begin{tabular}{ll} 
& \multicolumn{1}{c}{ ST strategy } \\
a. & Always innovating by presenting \\
new things about NTT culture so \\
as not to lose its attractiveness and \\
be able to compete with cultures \\
from areas outside NTT \\
b. $\quad$ With a lot of creativity and \\
numbers, communities can \\
organize their own events without \\
having to wait for government \\
intervention \\
c.
\end{tabular} & $\begin{array}{l}\text { a. Keep practicing and familiarise } \\
\text { the community to continue to } \\
\text { integrate cultures in NTT in } \\
\text { appearance } \\
\text { b. Creating classes or courses to } \\
\text { recruit new members and } \\
\text { mentally train new members to be } \\
\text { confident } \\
\text { c. Create a modern dance workshop } \\
\text { by combining cultural elements } \\
\text { in it }\end{array}$ \\
\hline
\end{tabular}




\begin{tabular}{|l|l|l|}
\hline d. $\begin{array}{l}\text { Lack of intervention by the } \\
\text { government in helping promote } \\
\text { cultural tourism in NTT, thus } \\
\text { making modern dance communities } \\
\text { in Kupang City always move on the } \\
\text { basis of togetherness only }\end{array}$ & $\begin{array}{l}\text { through social media during a } \\
\text { pandemic } \\
\text { Cooperating with various related } \\
\text { parties who are able to support } \\
\text { tourism development, such as the } \\
\text { tourism office and the } \\
\text { development of internet } \\
\text { technology so that it can be used } \\
\text { as a promotional tool. }\end{array}$ & $\begin{array}{l}\text { Continue to learn and expand } \\
\text { knowledge about culture in NTT } \\
\text { currently happening is the Covid- } \\
19 \text { outbreak }\end{array}$ \\
$\begin{array}{l}\text { The work of modern dance } \\
\text { communities from areas outside } \\
\text { NTT that are able to compete with } \\
\text { modern dance communities in } \\
\text { Kupang City }\end{array}$ & & \\
\hline
\end{tabular}

After compiling the SWOT Matrix, Strategy Priority Determination is carried out. Strategy prioritization is carried out to see the modern dance community's appropriate and good strategies in promoting cultural tourism in NTT in the SWOT matrix analysis of internal and external factors. Based on the SWOT matrix results and research on the modern dance community in Kupang City, the strategic priority applied is the ST strategy. After obtaining a strategy, it is then sorted according to the most effective strategy to be a strategic priority in promoting cultural tourism in NTT. The determination of the ST linkage strategy can be seen in the following table:

Table 2. Strategic Priority Determination

\begin{tabular}{|l|l|}
\hline \multicolumn{1}{|c|}{ Strategy } & \multicolumn{1}{|c|}{ Linkages } \\
\hline $\begin{array}{l}\text { Cooperating with various related parties who are able to support tourism development, } \\
\text { such as the tourism office and the development of internet technology so that it can be } \\
\text { used as a promotional tool. }\end{array}$ & S4 \\
\hline Creating online competitions through social media during a pandemic. & $\begin{array}{l}\text { S2, S5, S6, } \\
\text { T2, T5 }\end{array}$ \\
\hline $\begin{array}{l}\text { Always innovating by presenting new things about NTT culture so as not to lose its } \\
\text { attractiveness and be able to compete with cultures from areas outside NTT. }\end{array}$ & $\begin{array}{l}\text { S1, S3, T1, } \\
\text { T3, T6 }\end{array}$ \\
\hline $\begin{array}{l}\text { With a lot of creativity and numbers, communities can organize their own events } \\
\text { without having to wait for government intervention }\end{array}$ & $\begin{array}{l}\text { S3, S4, T2, } \\
\text { T3, T4 }\end{array}$ \\
\hline
\end{tabular}

Based on the table above, it is found that the priority strategies of the modern dance community for tourism promotion in NTT are as follows:

The community has many acquaintances as one of its strengths. This can be used to collaborate with related parties who are able to support the development of cultural tourism promotion, such as the tourism office and Internet technology so that it can be used as a means for promotion. Cooperation with related parties can assist communities in the form of funds etc.

The current pandemic period makes it very difficult for the community to work due to the lack of events and competitions as a forum to distribute their work. So the only way to overcome this threat is to create online competitions. In addition to overcoming the threat from the pandemic period, strategies can also overcome the threat of loss of attractiveness because there is strength in the form of being able to entertain the audience, it is an interesting and unique area through social media so that people who are outside the region can help spread information about the competition being held covering more participants and spectators who are outside the area.

With the proficiency in dancing and creativity in the modern dance community, the community can innovate to present new and exciting things about NTT culture so that it can attract the attention 
of the audience so that it does not lose its attractiveness and is able to compete with cultures from other regions.

The strength of the community is in the form of creativity, the number of members, where many communities can create their own events without having to wait for government intervention so that they can overcome the threat of lack of interference from the government, be able to compete with activities or events outside the NTT area and add events for the modern dance community to channel talent they.

\subsection{Discussions}

Based on the results of the above research, it can be seen that the modern dance community in Kupang City has considerable potential in helping to promote cultural tourism in NTT. With the creativity and innovation of modern dance communities in Kupang City, it is a special attraction to attract tourists. However, in the promotion process, the modern dance community still has several weaknesses and threats that prevent the community from promoting cultural tourism in NTT, for this reason the researchers analyzed by utilizing the abilities and opportunities owned by the community to minimize weaknesses and avoid threats that the community has so can help the process of promoting cultural tourism in NTT.

According to observations made by researchers, by going directly to the field to observe, the issue of funding has indeed become a problem that cannot be avoided because the funds needed are large enough to integrate cultural concepts into modern dance performances. Starting from the costume, where the costume that is worn when performing it is impossible to buy a costume that has been made immediately. The costumes worn must be modified in such a way as to further accentuate the NTT culture in it. Then the funds needed start from the purchase of materials to make costumes to the cost of paying the tailors to make costumes, the price to pay the tailors also depends on the level of difficulty and the costume design. As for the costumes that have been made immediately, the price will be more expensive than those made by the community and the number is not necessarily the same as the number of dancers who will appear. Usually the funds for this costume are obtained from a joint venture of the dancers who will appear.

In addition to costumes, if there is competition, the community needs funds to pay for the registration fee. Usually, the community registration fee uses the money obtained from each dancer's joint venture from the team that will perform. There is also a use of cash from the modern dance community itself obtained from the winner of the previous competition, but if you don't win, it means that there is no income for the team's cash. Even then, for competitions in the city of Kupang or around the NTT area, if you want NTT cultural tourism to be better known to people outside the NTT area, the Kupang City modern dance community can take part in a more prestigious competition event outside the NTT area by integrating NTT culture into their appearance. But back again to the funds or costs needed by the modern dance community, starting from transportation costs, lodging costs, living expenses such as consumption of dancers while in the competition area. It is not certain that the modern dance community from Kupang City will win the event because competition from other regions is no less attractive.

The question here is, why is the money from the winner in the competition not sufficient for a modern dance community? When a community wins a champion in a competition, the winning money will be divided equally among the coaches and dancers who appear in the competition, if there is any money leftover from the equal share, then it will be put into the team cash Earning money from winning results is also one of the motivations for a dancer to participate in performing and being able to pay for the hard work of training conducted by a modern dance community. This can answer the question above why the money won by a modern dance community is insufficient to help promote cultural tourism in NTT. 
The following problem for the modern dance community is about government interference. According to researchers' observations, the government does not pay attention to the modern dance community in Kupang City as a community capable of promoting cultural tourism in NTT. However, from 2018 to 2019 the government of the Kupang City Tourism Office has made an annual event every December in the form of a modern dance competition, which requires participants to incorporate cultural elements into their appearance as one of the assessment criteria to win championships.

However, on October 2, 2020, when the researcher went to the Kupang City Tourism Office to make a research permit, the researcher received information from Mr. Jefri Cornianto Adoe, SE as Head of the Tourism Destination Division at the Kupang City Tourism Office, that this annual event will not be held in 2020 due to the pandemic period caused by Covid-19 which is currently happening.

From the observation of the problem regarding the lack of government intervention above, the researcher concluded that why most of the informants said this was a problem for the modern dance community because the modern dance community felt that there was still a lack of events that helped the community promote cultural tourism in NTT. So the community is only able to promote NTT cultural tourism once a year. For that, the modern dance community needs more events to showcase their work. Apart from events, the modern dance community also wants government assistance, such as supporting communities to participate in events outside the NTT area. The assistance needed is such as funding assistance so that it can solve the main problem, namely regarding funds as described above.

After the researcher found the various problems above, the researcher used a SWOT analysis to determine what internal and external factors possessed by the modern dance community to determine what strategies are appropriate to be implemented in promoting cultural tourism in NTT by interviewing 15 dancers in Kupang City.

After analyzing internal and external factors using SWOT analysis, a grand matrix strategy and SWOT matrix analysis are used to determine the community's strategies to promote cultural tourism in NTT based on these internal and external factors. Then to find the right strategy to use, a prioritized strategy was determined for the community to implement in promoting cultural tourism in NTT.

1. Cooperating with various related parties capable of supporting tourism development, such as the tourism office and the development of Internet technology, can be used as a promotional tool.

2. Creating online competitions through social media during a pandemic.

3. Always innovating by presenting new things about NTT culture so as not to lose its attractiveness and be able to compete with cultures from areas outside NTT

4. With a lot of creativity and numbers, communities can organize their own events without having to wait for government intervention.

5. Integrating NTT cultural elements in participating in competitions or filling in events at events so as to increase community awareness about the importance of NTT cultural tourism and earn money when winning championships or being paid for filling events.

6. Uploading dance videos mixed with NTT culture to social media so that they can attract people's attention so that they are interested in joining modern dance so that they can get new dancers and get good training.

7. Keep practicing and familiarise the community to continue to integrate cultures in NTT in appearance.

8. Creating a modern dance workshop by combining cultural elements in it.

9. Creating classes or courses to recruit new members. 


\section{Conclusion}

Based on the results of the previous research and discussion, it can be concluded that to determine the strategy of the modern dance community in promoting cultural tourism in NTT, the researchers used the SWOT analysis in this study to observe what are the strengths, weaknesses, opportunities. and threats. After that the researcher used the grand matrix strategy and the SWOT matrix strategy and then determined the strategic priorities in order to easily find the most appropriate strategy for the modern dance community in promoting cultural tourism in NTT and obtain the following strategies:

1. Cooperating with various related parties capable of supporting tourism development, such as the tourism office and the development of internet technology so that it can be used as a promotional tool.

2. Creating online competitions through social media during a pandemic

3. Always innovate by presenting new things about NTT culture so as not to lose its attractiveness and be able to compete with cultures from areas outside NTT

4. With a lot of creativity and numbers, communities can organize their own events without having to wait for government intervention

\section{Limitation and Study Forward}

This study provides an overview of tourism promotion efforts through the commodification of modern dance in East Nusa Tenggara. However, the description described, data processing, and the findings in the study cannot be used as general conclusions about tourism promotion or the commodification of modern dance. This study only focuses on the phenomena that occurred in East Nusa Tenggara specifically among Modern Dance dancers. For further researchers, they can carry out deeper research using a quantitative approach to allow scientific comparisons with two different approaches.

\section{References}

Ahimsa-Putra. (2004). Pariwisata Indonesia Vol 4: pariwisata budaya dan budaya pariwisata Amstrong, G (2010). Prinsip-prinsip pemasaran ed.14. Erlangga.

Barker, C. (2005). Cultural studies: teori dan praktik (terj). Bentang.

Dewi, A. P. (2016). Komodifikasi tari barong di pulau Bali (Seni Berdasarkan Karakter Pariwisata)

Dewi, F. K., Nirawati, M. A., \& Yuliarso, H. (2016). Pusat tari modern dengan pendekatan arsitektur metafora di Yogyakarta. Arsitektura, 14(2).

Gromang, Frans. (2003). Manajemen kepariwisataan. Pradnya Paramita.

Horosko, M. (2002). Martha Graham: the evolution of her dance theory and training. University Press of Florida.

ICOMOS, G. A. (1999). International cultural tourism charter, managing tourism at places of heritage significance. 2012 - 05-08]. http://www. intema — tiona1. icom os. org/charters/tourism _ e. pd 1999-10.

Irianto, A. M. (2016). Komodifikasi budaya di era ekonomi global terhadap kearifan lokal: studi kasus eksistensi industri pariwisata dan kesenian tradisional di Jawa Tengah. Jurnal Theologia, 27(1), 212-236.

Kotler, P., \& Armstrong, G. (2010). Principles of marketing. Pearson education.

Kotler, P., \& Keller, K. L. (2009). Dirección de marketing. Pearson educación.

Laili, A. (2016). Hip-Hop Dance dalam persepsi masyarakat Jawa di kabupaten Sidoarjo (Doctoral dissertation, UIN Sunan Ampel Surabaya).

Lukmantoro, T. (2004). Ritual hari raya agama: histeria konsumsi massa dan khotbah industri budaya. 
Mayasari, D. (2014). Strategi promosi pariwisata pulau Derawan (Studi deskriptif kualitatif strategi promosi dinas pariwisita kabupaten berau kalimantan timur dalam upaya menjadikan pulau derawan sebagai tujuan wisata) (Doctoral dissertation, Universitas Muhammadiyah Surakarta).

Mbuik, N. A. F. (2013). Perancangan media promosi pariwisata provinsi Nusa Tenggara Timur. Skripsi. Universitas Negeri Yogyakarta.

McKercher, B. (2002). Towards a classification of cultural tourists. International journal of tourism research, 4(1), 29-38.

McKercher, B., \& Du Cros, H. (2002). Cultural tourism: The partnership between tourism and cultural heritage management. Routledge.

Muhammad, Z. (2013). Analisis kepuasan wisatawan ditinjau dari segi unsur-unsur komunikasi pada pagelaran seni pertunjukan di saung angklung Udjo (Doctoral dissertation, Universitas Pendidikan Indonesia).

Mulyani, N. (2016). Pendidikan seni tari anak usia dini. Yogyakarta: Penerbit Gava Media.

Nafila, O. (2013). Peran komunitas kreatif dalam pengembangan promosi pariwisata budaya di situs megalitikum Gunung Padang. Jurnal Perancaan Wilayah dan Kota, 24(1).

Nurdiansyah. (2014). Peluang dan tantangan pariwisata Indonesia. Alfabeta, Bandung.

Nurulwasi, M. M. (2017). Analisis strategi promosi dalam pengembangan pariwisata.

Paok, V. T. (2012). Komodifikasi dalam program pengembangan seni budaya di Jogja TV. Universitas Atmajaya Yogyakarta.

Piliang, Y. A. (2004). Dunia yang dilipat: tamasya melampaui batas-batas kebudayaan. Jalasutra.

Pitana, I. G., \& Gayatri, P. G. (2005). Sosiologi pariwisata: kajian sosiologi terhadap struktur, sistem dan dampak-dampak pariwisata. Andi

Sendra, I (2013). komodifikasi informasi pariwisata budaya fungsi dan makna upacara memasuki usia dewasa di Jepang dan Bali: perspektif lintas budaya. Analisis Pariwisata, 13(1).

Shepherd. (2002). Commodification culture and tourism. 2.

Soebagyo (2012). Strategi pengembangan pariwisata di Indonesia. Jurnal Liquidity, 1(2).

Soeriaatmaja, A. R. (2005). Peran penataan ruang tapak pada pengembangan pariwisata budaya tradisional. dalam MP Gunawan, pariwisata budaya dan budaya pariwisata. Bandung: Institut Teknologi Bandung.

Sunaryo, B. (2013). Kebijakan pembangunan destinasi pariwisata konsep dan aplikasinya di Indonesia.

Suranti, R. (2005). Pariwisata budaya dan peran serta masyarakat. In Workshop wisata budaya bagi kelompok masyarakat provinsi DKI Jakarta (Vol. 12).

Suryadana, M. L., Vanny, O. (2015). Pengantar pemasaran pariwisata. Alfabet.

Thei, Y. P., Fanggidae, A. H., \& Fanggidae, R. E. (2019). Analysis of the effect of the commodification Sotis woven fabric on hotel occupancy rates (Case study on local hotel brandhotels Sotis Kupang). In International Conference on Tourism, Economics, Accounting, Management, and Social Science (TEAMS 19). Atlantis Press.

Timothy, D. J., \& Nyaupane, G. P. (Eds.). (2009). Cultural heritage and tourism in the developing world: A regional perspective. Routledge.

Tjiptono, F (2019). Strategi Pemasaran.

Utomo, S. W., Soeparman, H., \& Sapto, B. (2014). Kajian kritis dampak perkembangan pariwisata terhadap eksistensi budaya Sunda di Kota Bandung. Patanjala, 6(3), 447-460.

Widyasti, F. R., \& Farida, S. (2013). Strategi promosi wisata pada dinas Kebudayaan, Pariwisata, Pemuda dan Olahraga Kabupaten Temanggung. Yogyakarta. Skripsi online.

Yonathan, M., \& Misbahuddin Azzuhri, S. E. (2012). Peranan dinas pariwisata dan kebudayaan kota batu dalam kegiatan promosi pariwisata Kota Batu. Jurnal Ilmiah Mahasiswa FEB, 1(1). 
Yuniarvi, R. P. (2017). Struktur dan bentuk tari modern Semarang dance lovers (Doctoral dissertation, Universitas Negeri Semarang).

Zuhdin, A., Amelia, R., \& Syukur, M. (2015). Laporan hasil penelitian kolektif: analisis SWOT. 